\title{
TEATRO DE TRANSIÇÃO NOS PALCOS CURITIBANOS DE 1919
}

Marta Morais da Costa*

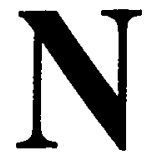

a inter-relação arte-realidade, o teatro exemplifica ao longo dos tempos uma multiplicidade de maneiras de encontro e de dessemelhanças. A materialização do discurso espetacular - idiossincrasia da arte teatral - se dá na dependência das variadas circunstâncias ditadas pelo real: as técnicas interpretativas dos homens-atores, a capacidade financeira da companhia, a concretização técnica de cenários, adereços e figurinos, a presença física do público, a estrutura arquitetônica do teatro, o clima, os meios de transporte e muitos outros mais.

Em consequiência, a história do teatro contém exemplos da infinita variedade de formas com que arte e realidade se misturam, se contrapõem, se completam. Destacar esta ou aquela época, companhia ou texto pode trazer à luz da análise considerações e conclusões de importância capital para a compreensão do fato teatral. Há, inclusive, épocas em que a quantidade de exemplos torna-se vultosa e rica pela repetição ou pela contraditoriedade, confirmando, assim, as dimensões históricas do real.

Ao seccionar da história do teatro em Curitiba o ano de 1919, buscamos compreender um momento em que o teatro brasileiro e o local viviam a conturbada espera da mudança bem representada pelo Modernismo, entrevista, no entanto, já nos anos imediatamente anteriores.

Porque dispomos de parâmetros mais seguros, criados pela distância

* Universidade Federal do Paraná e Pontifícia Universidade Católica do Paraná 
COSTA, M. M. Teatro de transição...

temporal, podemos retroagir e identificar em que manifestações é possível descobrir os anúncios modernistas e a permanência dos valores oitocentistas. Esse olhar comparativo se completa pela implícita ocorrência da determinação das características desse teatro: é preciso qualificar para depois comparar.

As fontes de informação dos acontecimentos teatrais de 1919 em Curitiba são os jornais diários, as revistas, os depoimentos autobiográficos e a história do período. É possível deduzir, de início, que a realidade de que falamos aqui é aquela construída por esses textos que supõem descrevê-la.

A vida teatral da cidade estava situada na região mais central. Na rua Dr. Muricy ficava o teatro municipal, o Guaíra. Na rua XV de Novembro, sua perpendicular importante mais próxima, ficavam os vários cine-teatros: o Elegante, o Central, o Palácio. A espacialização deixa entrever a relação entre o eixo central em que ficavam lojas, repartições públicas, redações de jornais e o clube social mais elegante - o Club Coritibano - com os locais de diversão, como cinemas e teatros. A comodidade de locomoção, além do maior cuidado urbanístico, serviam de atrativo para os diferentes públicos. Não se pode negar, porém, que a vizinhança próxima criava também liames sociais e econômicos. A distância do centro criava um outro teatro, suburbano, operário, popular. Mas sobre este, os periódicos frequientemente silenciavam.

O crescimento urbano pode ser detectado não apenas no povoamento cada vez mais intenso dos bairros (Água Verde e Batel, por exemplo) mas também na melhoria urbanística da região central, cada vez mais dotada de dispositivos comerciais e de serviços para o atendimento da população. $O$ teatro participa sem dúvida do esforço de converter a cidade em pólo cultural e em símbolo de afirmação de modernidade.

Neste sentido, a defesa que o jornalista Gastão Faria realiza em 7 de janeiro de 1919 pelas páginas do Diário da Tarde é exemplar. Ao comentar as diferenças entre o Rio de Janeiro e Curitiba, fica patente no artigo a diferença entre a então capital federal e a província. $O$ artigo tem a intenção de alertar para o excessivo elogio que a imprensa carioca costuma atribuir às companhias itinerantes quando se dirigem aos demais estados do país. Isto porque as críticas formuladas no centro cultural do Brasil eram utilizadas como publicidade nas temporadas das companhias. Ocorre que Curitiba já havia recebido elencos fraquíssimos e o público havia sido ludibriado pela propaganda enganosa.

Em 25 de dezembro de 1918, havia estreado a Troupe Guanabara da atriz Claudina Montenegro, precedida por comentários elogiosos provindos da imprensa carioca. $\mathrm{O}$ repertório era de uma mediocridade ímpar e o elenco deixou muito a desejar, de tal maneira que o público foi gradativamente se ausentando dos espetáculos e a companhia não teve dinheiro nem para pagar a hospedagem 
no hotel. Em 11 de janeiro de 1919, os artistas remanescentes deram um espetáculo em reprise a fim de angariar fundos para a viagem de volta ao Rio de Janeiro.

Gastão Faria defende que “... não devemos ir pedir lições ao Rio de Janeiro. $\mathrm{O}$ nosso progresso intelectual é suficiente para nos dar o necessário critério para o bom julgamento." E não hesita em declarar guerra à crítica jornalística carioca:

Quando uma companhia teatral mambembe ou um artista quer fazer a sua vida, faz em primeiro lugar a vida dos jornais. Paga-os muito bem. Dá-lhes anúncios caros.

E, a saida do jornal, já se sabe: o elogio é barulhento e convincente. A gente própria fica na dúvida. (...)

Não nos subordinemos às opiniōes lá emitidas. Analisemos acuradamente de um modo todo pessoal. O Rio mente.

Não mintamos à nossa consciência.

Analisemos. 2

Ficava assim desvendada a ligação de favores entre jornalistas e elencos, mediada pela publicidade, essa nova linguagem motriz do imaginário da sociedade capitalista.

O esforço de afirmar a soberania da cidade nas decisões de toda ordem leva ao aparecimento de alguns artigos que demonstram como as questōes relativas ao conceito de nação e de federação estavam sendo tratadas. Em 6 de fevereiro, Pamphilo d'Assumpção, jornalista e professor, defendia o regionalismo e as então denominadas províncias no artigo "Província, provincianismo, provinciano". A base de sua argumentação é a igualdade federativa, de que o Rio de Janeiro apenas se distingue por ser o "centro constitucional da administração do país e nada mais". A consciência de um modo de ser político, moral e cultural diferenciado fazia o articulista expressar uma reivindicação que vinha ao encontro da independência defendida por Gastão Faria:

Vinte e quatro milhões de habitantes não podem ser guiados nem inspirados por um milhão de homens, dos quais a maior parte

1 FARIA, Gastão. Criterrio adotado para o elogio de artistas no Rio. Diário da Tarde, Curitiba, p. 1, 7 jan. 1919.

2 Id. 
COSTA, M. M. Teatro de transição...

não conhece nem os hábitos, nem os ideais, nem o poder moral e físico desse povo, tão desdenhosamente tratado como provinciano.

Desse povo com quem a capital faz a partilha do leão ao distribuir o resultado do trabalho do país, e que, entretanto, é quem produz, quem trabalha, quem faz a riqueza da Nação.

Não é justo, pois, esse epíteto irritante de provinciano, não se justifica que nós o aceitemos resignadamente. ${ }^{3}$

$\mathrm{Na}$ mesma linha de reflexão a respeito do conceito de nação, surgem pequenos textos a favor e contra o governo do proletariado, na esteira da Revolução Bolchevique de 1917, na Rússia. Alguns pequenos textos davam conta do repúdio "à anarquia do Maximalismo" " ou dos direitos do proletariado, advertindo que "O capitalista deve ser um procurador da coletividade e não um explorador dela." 5

Esse debate político e ideológico prolongar-se-á ao longo do ano de 1919, adotando coloração mais ou menos intensa com a provocação nascida dos fatos sociais e culturais. A polêmica a respeito das idéias socialistas e anarquistas traz para os jornais algumas exposições interessantes, mais ou menos catastrofistas, mais ou menos desinformadas. Em 4 de setembro desse ano, o Teatro Guaíra abre as portas para a conferência de José Simões Coelho, redator do jornal $O$ Século, de Lisboa, intitulada "O Espantalho do Maximalismo", destinada a serenar os conservadores locais, mostrando o movimento de reivindicação dissociado das conturbações operárias. É possível verificar na fala do jornalista pontos em comum com a literatura de Monteiro Lobato e a idealização de um movimento de paz social sem sangue, alimentada por um nacionalismo ainda romântico:

No Brasil o Maximalismo assume aspecto diverso. Num território enorme, fertilíssimo e despovoado, o jeca Tatu (sic) não tem mais que levantar o braço e colher banana; abaixar-se um pouco e arrancar a mandioca. Daí a ausência de motivos para uma revolução social.(...)

3 ASSUMPÇÃO, Pamphilo d'. Província, provincianismo, provinciano. Diário da Tarde, Curitiba, p. 2, 6 fev. 1919.

4 LISBOA, Osmindo. O maximalismo. Diário da Tarde, Curitiba, p. 2, 17 jan. 1919.

5 FARIA, Gastão, ... porque o proletariado na miséria tem razão. Diário da Tarde, Curitiba, p. 1, 14 fev. 1919. 
Assim no Brasil a revolução social terá de vir de cima para baixo, do legislador para o povo e sem violências inúteis, como nas nossas grandes revoluçōes nacionais, feitas sem sangue e sem os exageros engendrados pela miséria.

E o Maximalismo impondo-se, fará a socialização da produção e o povo, liberto do analfabetismo, há de compreender a excelência dessa nova fórmula da felicidade humana. ${ }^{6}$

O assunto não desapareceu dos jornais. Vez por outra retornava, sempre sob forma polêmica, nas primeiras páginas. Em 15 de outubro, as iniciais A. G. camuflavam o autor de um pequeno texto com o título "O Comunismo". Ao final de uma argumentação apoiada nas greves reivindicatórias dos operários curitibanos, lançava uma predição otimista: "O capitalismo e a burocracia terão que ceder ao operariado soberano e vitorioso e no dia de amanhã a sociedade terá como base sólida e segura o trabalho honesto e dignificante, extinguindo-se por completo a eleição pelo sangue ou pelo dinheiro, ridícula e injusta. Será o domínio das capacidades do valor individual."7 Predição caída no abismo das utopias.

Convém ressaltar que esta questão social não esteve contemplada de maneira alguma pelo teatro, criando um abismo entre as discussões presentes na realidade e a vida representada no palco.

É possível observar que a desintegração da Troupe Guanabara deixou semeada a desconfiança no público. Escaldados, os empresários evitaram trazer a Curitiba companhias forasteiras. Até o mês de setembro de 1919, a cidade viveu de espetáculos amadores locais e de uma pequena companhia de variedades infanto-juvenil, a dos Irmãos Karr.

A participação dos amadores na história do teatro na cidade foi sempre sem esmorecimento. Muitas agremiações sociais abrigavam um grupo teatral. Profissionais de diferentes áreas também se faziam representar no palco: militares, operários, profissionais liberais. Algumas escolas estimulavam os alunos a apresentações pontuais em datas cívicas ou em final de ano. Outras agremiações reuniam participantes das mais diversas origens com a finalidade precípua de organizar festivais, saraus e representações teatrais. Desta forma, a cidade podia registrar uma movimentação incessante nos palcos.

Pode ser registrada no primeiro semestre de 1919 a participação do Grêmio 19 de Julho, do Conservatório de Música do Paraná, com um fragmento

6 O espantalho do maximalismo. Gazeta do Povo, Curitiba, p. 1, 5 set. 1919.

7 A. G. O Comunismo. Gazeta do Povo, Curitiba, p. 1, 15 out. 1919. 
COSTA, M. M. Teatro de transição...

da ópera Papilio Innocentia, de Emiliano Pernetta e Léo Kessler, o Grupo de Amadores Roando, o Grupo Filodramático Dante Alighieri, o Grupo Escolar Modelo, o Grêmio das Violetas, o Grêmio Estrela d'Alva, a Escola Americana, os Grupos Escolares Rio Branco e 19 de Dezembro, além de espetáculos beneficentes que reuniram artistas de diferentes agremiações.

É possível conhecermos um pouco do repertório dos festivais quando os jornais reservam um espaço para reprodução de um programa detalhado, o que era comum na época. Foi o que ocorreu quando, em 29 de março, foi homenageado o escritor e crítico Nestor Victor:

PRIMEIRA PARTE

1. Banda da F. M. do Estado - T. Wettge Cicé - Ouverture.

2. Dr. Santa Ritta - Discurso.

3. Tenor Alexandre Mey - II Fiore (Carmen, de Bizet); Luccevan le stelle (Tosca, de Puccini).

4. Dr. Lacerda Pinto - Poesia.

5. Senhoritas Maria e Heloisa Guimarães - Violino e piano, Concerto de Mendelssohn, op. 4, $1^{\circ}$ tempo.

6. Dr. Seraphim França - Recitativo humorístico.

7. Senhorita Hermínia Sengés - Canto a) Aleluie d'amour - J. Fabre; b) Adieu (Manon, de Massenet).

8. Professor Raul Menssing - Piano, Sonata em Dó Maior op.53 (Waldstein) - Rondó (alegretto).

\section{SEGUNDA PARTE}

1. Banda da F. M. do Estado - P. Mascagni. Dança exótica.

2. Wenceslau Schwansee - Violino. Aria Zingaresca, de Sarazat, op. 20.

3. Senhorita Zilah Ticoulat - Dois sonetos.

4. Menino Victor Jamberelli - Tenor. Torna Sorriento.

5. Senhorita Emma Quaquarelli - Número de arte.

6. Francisco Leite - Poesia.

7. Mme. Naná Sengés Pinto-Piano. a) Rondó caprichosoMendelssohn. b) Noturno op. 15 n.2 - Chopin.

8. Dario Velloso - Palavras.

9. Nestor Victor - Palavras.

A programação nada apresenta de inovador. Serve, contudo, para aferir o gosto e o repertório musical dos amadores. Nada nele denuncia uma tendência 
nacionalista. Ao contrário, a presença da cultura européia é forte, principalmente a que chega trazida pela ópera e pela opereta. Já na literatura, a presença de poetas paranaenses declamando suas composições em homenagem ao crítico literário em evidência no Rio de Janeiro faz supor textos de encomenda, escritos para o festival. De qualquer forma, tratava-se de um festival com as marcas do regionalismo: de paranaenses para paranaenses.

Comemorando a data da Independência, e como não poderia deixar de ser, um outro concerto privilegiou compositores nacionais. Foram executadas peças do repertório de Carlos Gomes, Henrique Oswald, Artur Napoleão, Alberto Nepomuceno e o paranaense Augusto Stresser. Voltou a ser apresentada uma ária de Papilio Innocentia, com cenário bucólico especialmente preparado para a solenidade. É verdade que a data histórica restringia a importância das escolhas.

A propósito de dois pintores, o português Carlos Reis e o brasileiro Antônio Parreiras, o jornalista Gastão Faria volta a atacar o Rio de Janeiro, dessa vez para acusar a crítica carioca de preterir Parreiras, exclusivamente por ser brasileiro, e usa como argumento a mentalidade colonial de que o Brasil ainda estava imbuído. No fragmento que se segue, é possível observar a presença do pensamento de Manuel Bandeira ("macaqueamos a sintaxe lusíada"), dos princípios modernistas do "ruim mas nosso", além, é claro, do citado Monteiro Lobato:

Somos aqui esse Jeca Tatu que a admiração popular, depois do aparecimento do Urupês, celebra por toda parte.

Ridicularizando o famoso Jeca, não nos lembramos que ele encarna em si todos nós.

Vivemos imitando. Nada queremos produzir.

E quando a Europa nos despeja as suas drogas, para cima delas avançamos deslumbrados, como o indígena de tempos idos avançava para as miçangas que os catequisadores lhes davam. ${ }^{8}$

É flagrante a discrepância entre as idéias defendidas pelo jornalista e a programação de amadores e profissionais. À exceção das montagens de dramaturgos paranaenses, levados ao palco mais por um desejo de prestigiar o artista local do que para se opor à invasão de textos estrangeiros, o repertório dos

8 FARIA, Gastāo. No Brasil só procuramos elevar artistas de outras terras. Diário da Tarde, Curitiba, p. 1, 9 maio 1919. 
COSTA, M. M. Teatro de transição...

amadores reproduzia os sucessos trazidos por companhias forasteiras. Desta forma, eram mais freqüentes as representações de revistas portuguesas, de zarzuelas espanholas, de operetas e vaudevilles franceses do que burletas, revistas e dramas brasileiros.

A exceção à avalanche de textos estrangeiros residia nas montagens de espetáculos com personagens e situações denominadas "caipiras", seguindo a influência do caipira idealizado de Catullo da Paixão Cearense, da visão crítica de Monteiro Lobato e da exploração cômica do teatro de Artur Azevedo e Bastos Tigre. Com uma peça deste ultimo, Seu Coroné, estréia em 4 de setembro a Companhia Pinto Filho, que cumpriria temporada até o dia 25 , sendo substituída de imediato pelo humorista "caipira" Batista Júnior, pai das futuras cantoras Linda e Dircinha Batista.

Seu Coroné obteve sucesso desde a estréia, graças ao desempenho dos atores e à comicidade do diálogo e das situações. Mesmo assim, a companhia preocupou-se com o aspecto moral, expurgando do espetáculo trechos que pudessem ser considerados imorais. Se a montagem tornou-se com isso mais familiar, não agradou a todos: "A revista foi expurgada de todas as piadas picantes e pornográficas, fato este que, com certeza, não agradou a certas pessoas." vezes ao longo da temporada, sempre com casa cheia, fato raro no teatro da época.

Na mesma toada do espetáculo para rir utilizando personagens caipiras, Meu boi não morreu, de autor não nominado, também foi sucesso, principalmente porque o ator Pinto Filho "com a perícia de artista que lhe é habitual, fez o sertanejo, apresentando-se-nos o tipo perfeito do Jeca"10

O cronista teatral da Gazeta do Povo deixa entrever as disputas ideológicas na avaliação dos espetáculos. Ao analisar a revista Seu Tibúrcio vem aí, o jornal apresenta o seguinte comentário:

A revista, como tudo o que pertence ao gênero, é uma coisa sem pés nem cabeça, sem originalidade, ridícula e detestável.

Há nela cenas imoralíssimas de grande perversidade. No Palácio, todavia, a troupe vai alcançando sucessos diários, pois as revistas são ao sabor do paladar da platéia daquele teatro.

$\mathrm{O}$ desempenho foi bom. A orquestra desafinada, fora dos compassos, deplorável. "

9 Palcos e Telas: Companhia Pinto Filho. Diário da Tarde, Curitiba, p. 2, 5 set. 1919.

10 Palcos e Telas: Companhia Pinto Filho. Diário da Tarde, Curitiba, p. 5, 10 set. 1919.

11 Na tela e na ribalta. No Palácio. Gazeta do Povo, Curitiba, p. 4, 17 set. 1919. 
COSTA, M. M. Teatro de transiçāo...

Esse gênero dramático, na sua versão itinerante, não primava mesmo pelo respeito à qualidade. Antes favorecia a improvisação e o desleixo. Não fugiu dessa despreocupação com a arte a Companhia Pinto Filho: o último espetáculo da temporada, $O 31$, em 25 de setembro, teve o enxerto de cenas retiradas de outras revistas constantes no programa da Companhia. $O$ desrespeito com a autoria e o público fazia por desmerecer e deixar em alerta os espectadores mais conservadores em relação às revistas. De qualquer maneira, a comicidade, a crítica e o descompromisso manifestavam-se nos trocadilhos engraçados, nos versos e na música ligeira, nos cenários ricos em detalhes e na multiplicidade de formas musicais cantadas e dançadas: o rag-time, as canções e fados, os sambas e maxixes e os desafios ajudaram a formar o gosto popular do público, enquanto o rádio não chegava. Apenas em 1922 foi fundada a primeira emissora na cidade, a Rádio Clube Paranaense.

A popularidade das revistas se deveu à empatia que desde o início o gênero manteve com o público, dadas as peculiaridades de um teatro cômico e crítico numa linha de "carnavalização e malandragem que revestia a interpretação e o modo de vida brasileiros." 12 A revista veio interpretar os anseios de uma população mantida à margem do teatro, dito sério, dominante nos palcos oficiais brasileiros. Cumpre observar a ligação estreita entre os cronistas dos jornais urbanos, sempre prontos a criticar intensamente e a vigiar moralmente as revistas, mas complacentes com o teatro importado do Rio de Janeiro e São Paulo e das companhias estrangeiras. Daí porquê a insistência em salientar a moralidade dos enredos e da comicidade popular, como se fosse possível, com o artifício da exclusão, modificar a cultura do povo.

Acusada de comercial, obscena, superficial (o adjetivo na época era ligeira), a revista esteve relegada a teatros menores, dividia espaço com o cinema e o circo, mais comumente era avaliada pelas gargalhadas do público do que pelo teor crítico e político do enredo. De alguma forma, porém, a revista manteve a vitalidade e agilmente foi se transformando, porque estava ligada às mudanças de seu público fiel. Preservou a fala do povo, a proximidade com o social e o histórico e inaugurou uma nova forma de interpretação, em sintonia com o desejo do público. Desafiou o teatro importado e colocou-se à frente de um processo de criação do teatro nacional no século XX.

Paralelamente a esse movimento nacionalista da revista, havia uma moda caipira revelando-se em espetáculos mistos de teatro e variedades musicais. Assim, em 23 de setembro de 1919, os jornais anunciavam no complemento do

12 VENEZIANO, Neyde. Não adianta chorar: teatro de revista brasileiro... Oba! Campinas: Editora da Unicamp, 1996. p. 110. 
COSTA, M. M. Teatro de transição...

espetáculo da noite, a conferência caipira de Alfredo de Ferrante, seguida da paródia do Luar do Sertão, de Catulo, intitulada Luarr de Zante Gaterrines, em um cômico dialeto germano-brasileiro, interpretada pelo ator Conceição Machado. Pode-se ver nesta paródia uma linha de satirização à moda do dialeto ítalo-brasileiro de Juó Bananére em São Paulo.

A despedida da Companhia de Revistas Pinto Filho já estava sendo ofuscada pelos primeiros anúncios da chegada da Companhia Mexicana de Operetas Esperanza Iris, precedida pela reprodução de críticas exageradamente elogiosas, copiadas dos jornais cariocas. Era já o trabalho de marketing do empresário curitibano José Louzeiro, devido ao preço caríssimo das assinaturas (compra antecipada de ingressos para um conjunto de espetáculos) para a temporada. Enquanto a Companhia permaneceu em Curitiba, de 22 de outubro a 12 de novembro, houve sempre a alternância de elogios aos espetáculos e de crítica amarga ao preço dos ingressos.

Eram impressionantes para a época os números da companhia: 10 bailarinos, 40 coristas de ambos os sexos, mais costureiras, eletricistas e maquinistas e um repertório de 30 operetas. Tudo isso em espetáculos "exclusivamente para famílias"13. A publicidade foi intensa e secundada por crônicas, pequenas notas e até uma enquete a respeito das operetas preferidas que comporiam as récitas das assinaturas. Em ordem decrescente, o resultado apontou as seguintes peças: Casta Suzana, Mercado de Escravas, Eva, Rainha do Fonógrafo, Sonho de Valsa, Sangue de Artista, Viúva Alegre, Conde de Luxemburgo, Amor Mascarado, A Princesa dos Dólares e A Dama de Chez Maxim's. Esse conjunto indica que a escolha tendia a recair sobre operetas conhecidas e já apresentadas em Curitiba, evitando-se as novidades em nítida tendência conservadora.

A campanha publicitária rendeu imediatos resultados, apesar do valor elevado da assinatura. Em 3 de outubro, todas as frisas haviam sido vendidas, bem como metade das cadeiras da platéia. As crônicas teatrais ao longo da temporada registraram casa cheia em quase todos os espetáculos. Utilizando um termo da época, houve um verdadeiro frisson de arte nos meses da Esperanza Iris na cidade. O comércio de roupas, calçados, chapéus e flores - muitas flores para a atriz principal e dona da companhia - esteve aquecido.

Os textos críticos não regateiam adjetivos. Neles é criada a imagem de uma mulher-atriz sedutora, talentosa e versátil. Ela encarnava o "prestígio da graça, da expressão e da elegância"14. A tal ponto os cronistas exercitaram a pena elogiosa que, em dado momento, um deles reconhece o excesso: "Iris fascinou a platéia. É escusado gastarmos mais adjetivos com a soberana atriz."15

14 Palcos e Telas. Diário da Tarde, Curitiba, p. 2, 23 out. 1919. 
COSTA, M. M. Teatro de transição...

Além do mais, os espetáculos primavam pelo luxo nos cenários e figurinos, de tal maneira que as jóias usadas pela protagonista em Duquesa do Bal Tabarin cram verdadeiras e somente o colar usado em cena por Esperanza Iris valia 100 contos de réis!

O entusiasmo foi tão grande que o então Presidente do Estado, Afonso Camargo, esteve presente a todos os espetáculos da temporada. Além do mais, o Estado a Prefeitura liberaram a companhia de todos os impostos, pagando-lhe ainda as despesas de viagem. A tal ponto os curitibanos foram calorosos que a Gazeta do Povo não hesitou em desmentir o conceito de que o público local era "coveiro das boas companhias e protetor de circo de cavalinhos" imagem, construída ao longo do tempo não condizia com o projeto da imprensa que visava divulgar a capital do Estado como uma cidade progressista e culta, por isso urgia desmenti-la.

Mesmo quando os espetáculos ou a interpretação dos atores decepcionava, a imprensa encontrava maneiras de desviar os adjetivos desairosos para construções de sentido mais agradáveis. Ao comentar o desempenho de Luz Gonzalez, uma atriz secundária da companhia, o jornalista exclama: "graciosíssima e vivaz, embora sem nenhum gênio criador e sem a convicção necessária, agrada sempre, todavia, pela graça natural e simples com que interpreta os seus papéis." ${ }^{17}$ Da mesma maneira, comentando a fraca montagem de Mercado de Muchachas, Gastão Faria adota mais um tom conselheiral do que crítico: "Causa admiração que a 'Esperanza Iris', depois de triunfar na representação das duas primeiras peças do seu repertório, levasse à cena a famigerada Mercado de Muchachas. (...) Não lhe ficará bem dormir sobre os louros alcançados...,18

Observe-se nos exemplos a seguir, que tomam como referência o mesmo espetáculo da opereta Sangue de Polaco, como os jornalistas ao falar de teatro insistiam em imagens retóricas pouco descritivas ou serviam-se de fórmulas educadas para chamar a atenção para erros de interpretação.

As danças, sobretudo, nos fizeram presente a vida campesina das nossas colônias mais conhecidas. E nas krakovianas (sic). bailadas pelas formosas e rútilas figuras de Maria e Mina Corio, surgiu mais compacta a alma graciosa e gentil do temperamento

15 Palcos e Telas. Diário da Tarde, Curitiba, (6443), p. 2, $1^{\circ}$ nov. 1919.

16 Gazeta do Povo, Curitiba, p. 4, 24 out. 1919.

17 Gazeta do Povo, Curitiba, p. 4, 6 nov. 1919.

18 FARIA, Gastão. Do meu canto. Diário da Tarde, Curitiba, p. 1, 25 out. 1919. 
COSTA, M. M. Teatro de transição... eslavo, tão dado aos fulgores insofreáveis de um temperamento
festivo.

Perdoem-nos as graciosas bailarinas, de quem aliás somos apreciadores, mas aquilo que vimos dançar ontem, nunca foi nem Cracoviana nem qualquer coisa que se pareça como tal. Talvez que as gentis bailarinas soubessem que em nosso Estado grande parte da colônia estrangeira é polaca, não teriam anunciado nos cartazes a Cracoviana. ${ }^{20}$

De todo o elenco uma única pessoa atraía sempre a admiração dos jornalistas, a dona da companhia e primeira atriz. Não foi encontrado um único exemplo menos desairoso ao desempenho de Esperanza Iris. Ao contrário, os jornalistas hiperbolizaram todas as referências a ela:

Qucm viva na intimidade das palestras com a dama atenciosa e cheia de singeleza que é Esperanza Íris mal poderá presumir seja ela capaz de elevar tão arrebatadoramente a fisiologia e a fisionomia das expansões na modalidade segura das repentinas transições da alma. O seu trabalho de ontem [Sangue de Artista] foi uma coisa admirável, atingindo completamente ao sublime da revelação estética. Apreender e reter o difícil papel, sem um instante de descuido, sem um tempo de repouso, agitando a cena e fazendo sofrer corações, como se de fato realizasse ali a própria vida da artista, volúvel por profissão, leviana por conveniência, desdenhosa por costume, mas, no fundo, mulher amante e sofredora, eis o que com o máximo esplendor soube realizar a extraordinária e arrebatadora sra. Esperanza Iris. ${ }^{21}$

Era um teatro exemplarmente pré-modernista, de linha realista: as paixões pecaminosas vividas por personagens à margem do núcleo familiar e da burguesia. $\mathrm{O}$ encantamento por atrizes e bailarinas encontra na vida real um paralelo com a paixão de Oswald de Andrade por Landa Kosbach. Convém lembrar que não poucas vezes os papéis de atrizes e amantes misturavam-se,

19 Teatro Guaíra. Diário da Tarde, Curitiba, p. 5, 30 out. 1919.

20 Na tela e na ribalta. Gazeta do Povo, Curitiba, p. 4, 30 out. 1919.

21 Teatro Guaíra. Diário da Tarde, Curitiba, p. 2, 28 out. 1919. 
atendendo ao impulso do desejo e à realidade da vida cotidiana das cidades assumia essa confusão dos papéis: as atrizes tinham em seu passaporte como profissão a prostituição. Trata-se, portanto, de um encantamento pelo ilusório e uma mistura de arte e transgressão que povoa a literatura ao longo dos séculos.

Enquanto Esperanza Iris ocupava as noites do Guaíra, estreava no Cine Teatro Central, considerado o mais luxuoso da cidade, o artista paulista Batista Júnior. Em números solos, conseguia algum sucesso com o público mais popular do Central. Sem todo o suporte e luxo da companhia mexicana, ele apresentava

... um repertório inesgotável [composto por] palestra, canto e ventriloquia. Os seus monólogos caipiras são de uma comicidade extraordinária e diante de suas charges não há quem resista sem rir.

As suas canções são sentimentais, doridas, simples na feliz comparação do sertanejo, nas suas figuras acertadas, contando a sua vida despreocupada, dizendo hinos à natureza pródiga, à beleza do sítio, às águas cristalinas, aos campos verdejantes, enfim a tudo que canta e ri, ao sertanejo brasileiro bom, franco e leal. ...

É o artista brasileiro que canta o homem do sertão nacional, com amor, sem querer deprimi-lo, nem rebaixá-lo. Canta-o com sinceridade e patriotismo. 22

Este comentário evidencia que o universo ideológico por onde transitavam as operetas, misto de alienação e retrato burguês, assemelhava-se à concepção idealizada do sertanejo, interpretada por Batista Júnior. Na vida e na cultura ali representadas, podemos, encontrar ecos de um tardio Arcadismo, com pastores substituídos por homens de chapéu de palha e viola nas mãos.

A aparente contradição entre o luxo estrangeiro e a simplicidade caipira se anulava quando enfocada sob o ângulo ideológico: nenhum dos dois conseguia captar aspectos da realidade mais próxima. $O$ trabalhador urbano, o sertanejo de Canudos e mesmo o Jeca Tatu lobatiano aguardavam o nacionalismo crítico do Modernismo.

Enquanto a companhia mexicana cumpriu temporada, os jornais curitibanos $^{23}$ foram pródigos e benevolentes na exaltação dos méritos dos espetácu-

22 Palcos e Telas. Diário da Tarde, Curitiba, p. 3, 16 out. 1919.

23 Neste ano de 1919, circulavam em Curitiba 25 jomais e revistas. Havia periódicos 
COSTA, M. M. Teatro de transição...

los. Entre os poucos descontentes incluíram-se os porteiros do Guaíra - à exceção de um solitário discordante - que fizeram greve contra a companhia já no segundo espetáculo da temporada. $O$ motivo justificava a atitude: enquanto companhias mais pobres e menos festejadas lhes pagavam por noite de dois a quatro mil réis, a Iris se recusou a pagar mais do que mil e quinhentos a dois mil réis pelos mesmos serviços. Entre o guichê e a porta do teatro, a distância media-se pela intensidade da exploração do operário por seu momentâneo patrão.

Mas a cidade ganhava ares de metrópole aos olhos dos jornalistas, igualando-se aos centros teatrais mais importantes do país. A divulgação da imagem da capital civilizada se colocava como óbvia finalidade quando o cronista teatral se punha a descrever os aspectos sociais da temporada:

E o público como ontem, nem respeitando a grande chuva, aflui em compacta assistência aos espetáculos de Esperanza Iris; e a enorme movimentação que se nota ao sair, em frente ao Guaíra - uma multidão de automóveis, carros de praça, de bondes elétricos sob a intensa claridade dos grandes refletores do teatro - dispensa a nossa vaidade, afagada de entusiasmo pelo empolgante aspecto que a capital a essas horas apresenta. ${ }^{24}$

Sem dúvida alguma, a presença da companhia na cidade obteve, a acreditar no discurso intencionalmente deformador dos jornalistas, resultados imediatos na atração pelo teatro que perdurará até o final do ano. Luxo, operetas testadas e apreciadas, mulheres bonitas e subsídios governamentais compuseram a receita do sucesso para o palco curitibano.

Até mesmo o embarque para o Rio de Janeiro mereceu destaque e público. O Comércio do Paraná faz a cobertura do episódio para acentuar a civilidade dos curitibanos: "A gare abrigava grande número de pessoas, estudantes e demais admiradores(...) A hora 3 da manhã, o comboio pôs-se em marcha, ouvindo-se então muitas ovações populares, correspondidas pelos que partiam.

em polonês, italiano e português; alguns eram específicos - sobre espiritualismo, agricultura e medicina, por exemplo. É dos grandes jomais que a companhia recebe a melhor acolhida - Diário da Tarde, A República, Comércio do Paraná, Gazeta do Povo.

24 Teatro Guaíra. Diário da Tarde, Curitiba, p. 5, 25 out. 1919. 
(...) o derradeiro adeus daqueles que durante três semanas souberam conquistar as simpatias e os aplausos de uma culta platéia." 25

O balanço da temporada expressou bem a inter-relação entre arte, política e cultura, bem como serviu para divulgar ainda mais o conceito de capital progressista: "Ela soube levantar com sua brilhante troupe, o alvoroço geral no seio da nossa sociedade, para conquistá-la e atraí-la nas noites memoráveis de seus espetáculos. E nesse movimento simpático cria para nós o reerguimento de nosso teatro, da nossa platéia, dos nosso foros de cidade. E todos quantos se conglobaram em torno desse esforço só receberam aplausos e gratidão - população, governo e imprensa.",26

As companhias que vieram a seguir - a italiana de operetas de Clara Weiss e a brasileira de revistas e também de operetas do brasileiro Brandão Sobrinho - ficaram ofuscadas pelo brilho da Iris mexicana.

Com elas repetiu-se o duelo entre o artista forasteiro, de repertório e interpretação europeus, e o ator brasileiro, dotado de acentuada veia cômica mas cedendo parte do repertório ao gosto do público urbano. Como resultado, houve em curto espaço de tempo a repetição de operetas. A diferença é que o elenco brasileiro as cantava em português e as apresentava em um cine-teatro, receptivo a um público mais popular.

A imprensa deu longas crônicas a respeito da companhia italiana c relegou os brasileiros a pequenas notas sem destaque na página do jornal. Não se tratava exclusivamente de diferente repertório, mas de uma inclinação atávica de achar que o que vinha de fora era sempre melhor. Com o desenrolar da temporada, os jornalistas tiveram de ceder e reconhecer que a companhia do Teatro São Pedro não apenas atraía público mais numeroso como podia rivalizar em montagens caprichadas e interpretações adequadas.

Como de tradição, o olhar do jornal para a revista de costumes vinha intermediado por valores morais, principalmente quando se tratava de enfocar a cultura brasileira pelo viés da sensualidade. Um dos espetáculos de maior sucesso foi a revista de Bastos Tigre e João Foca, $O$ maxixe. É exemplar o comentário do jornalista do Diário da Tarde a respeito desse espetáculo:

Escoimada dos termos inconvenientes que tornam esse gênero de composiçōes teatrais pouco apreciadas das famílias, a revista de ontem é uma crítica muito interessante de alguns dos nossos nov. 1919.

25 O embarque da Companhia Esperanza Iris. Coméncio do Parand, Curitiba, p. 2, 13

26 Estação Teatral. Comércio do Paraná, Curitiba, p. 1, 12 nov. 1919. 
COSTA, M. M. Teatro de transiçāo...

costumes, constituindo um espetáculo agradável, por vezes hilariante, nele sobressaindo bons trechos de música popular e mirabolantes bailados nacionais.

Trata-se do eminente maxixe, que rompendo as brasileiras fronteiras, chegou até ao Boulevard de Paris, donde as Fifis vêm ver e aprender no Rio, fazendo a vida e a fortuna entre os "coronéis"... 27

A associação entre música brasileira, sensualidade e moral demonstram o estigma que atingia a música popular brasileira no início do século XX. Mário de Andrade em sua História da Música no Brasil confirma o preconceito contra o samba, sucessor do maxixe.

As revistas brasileiras da temporada tinham caráter documental. Por isso, uma delas, É o suco!, apresentava cenas de boêmia estudantil, "puro lirismo sertanejo" e cenas de rua.

Era Clara Weiss, porém, quem arrebatava a pena dos jornalistas, fazendoos expressar-se em linguagem nada analítica e muito semelhante à da coluna social dos periódicos. Observe-se a preparação que o Comércio do Paraná fez para o espetáculo em homenagem à atriz cantora:

Admirada e querida de nossa platéia onde colheu os melhores aplausos na transmutação diária dos personagens caprichosos que as operetas apresentam; dócil e amoldável às mais finas caracterizações dessas figuras gentis e luminosas, que as falenas rútilas das gambiarras teatrais; encantadora de verve e graça na travessura constante de seu olhar e de sua maneira adorável de dizer, - vence ainda as mais despreocupadas atenções pela doçura e delicadeza do seu canto, às vezes mais intenso de colorido e vigor, que a própria encantadora magia de seu formoso sorriso de onde ela promana na confusão da expressão. ${ }^{28}$

O desenho formado por esses espetáculos em nada permitia adiantar a revolução causada pelo Modernismo em, apenas, três anos mais. Na verdade, o teatro esteve ausente da rebelião modernista, como sabemos. A força das temporadas recheadas de operetas e de peças cômicas de molde operetístico não

27 Palcos e Telas. Diário da Tarde, Curitiba, p. 3, $11 \mathrm{dez} .1919$.

28 Estação teatral. Comércio do Paraná, Curitiba, p. 1, 23 dez. 1919. 
daria oportunidade para o surgimento de um público mais exigente do ponto de vista da renovação dramatúrgica ou espetacular.

Pode-se perceber que a presença repetida e bem-vinda dos personagens sertanejos e de seu linguajar característico nada tinha do espírito crítico macunaímico. Era, sobretudo, um forma exótica ou deliberadamente idealizada. No entanto, na delicada relação entre palco e platéia, sempre em busca da simbiose do sucesso, a constância do nacional acabou se sobrepondo à presença envolvente das companhias estrangeiras.

Do ponto de vista temático, nada anunciava nos espetáculos apresentados em 1919 em Curitiba o debate social e político, o deboche, a viagem em busca da descrição psíquica, ou, ainda, a paródia antropofágica.

Ao analisar uma temporada anual em Curitiba, confirma-se a distância que ainda separava o teatro brasileiro dos movimentos reivindicatórios de novas formas de expressão no palco. O século XIX continuava regendo o movimento teatral na cidade.

\section{RESUMO}

A temporada de 1919 nos teatros curitibanos contou com a Companhia de Operetas Mexicana de Esperanza Iris que fez ressurgir o movimento teatral na cidade, além de entusiasmar o público e os jornalistas com espetáculos de alto luxo e boa interpretação. Porém, malgrado todos os elogios tecidos, nem essas nem as demais companhias que se apresentaram em Curitiba deixaram entrever qualquer anúncio de novos tempos na arte de representar. $O$ teatro de sucesso continuava ignorando as manifestações nacionais às vésperas do Modernismo.

Palavras-chave: Teatro em Curitiba, Teatro Brasileiro, Pré-Modernismo.

\section{RÉSUMÉ}

La saison de 1919 aux théatres de Curitiba a presenté la Compagnie Méxicaine d'Operettes d'Esperanza Iris que a fait renaître le mouvement thêâtral en ville. Le publique et les journalistes se sont pris d'enthousiasme par les spectacles de grand luxe et d'une correcte interprétation. Mais, malgrè tous les éloges, aucune des compagnies que se sont présentées à Curitiba a laissé le public percevoir n'importe quel annonce des 
COSTA, M. M. Teatro de transição...

nouveaux temps de l'art de représenter. Le théâtre de succès ignorait les manifestations nacionaux aux moments qui antecédèrent le Modernisme.

Mots-clé: Théâtre à Curitiba, Théâtre brésilien, Pré-modernisme.

\section{REFERÊNCIAS BIBLIOGRÁFICAS}

Comércio do Paraná, Curitiba, 1919.

Diário da Tarde, Curitiba, 1919.

Gazeta do Povo, Curitiba, 1919.

VENEZIANO, Neyde. Não adianta chorar: teatro de revista brasileiro... Oba! Campinas: Editora da Unicamp, 1996. 